http://dx.doi.org/10.1590/0104-07072017003040015

\title{
RELATIONSHIP OF POLYPHARMACY AND POLYPATHOLOGY WITH FALLS AMONG INSTITUTIONALIZED ELDERLY
}

\author{
Karine Marques Costa dos Reis ${ }^{1}$, Cristine Alves Costa de Jesus ${ }^{2}$
}

\begin{abstract}
${ }^{1}$ Ph.D. in progress in the Post-graduate Nursing Program of the Universidade de Brasília (UnB). Secretary of Health Nurse of the Federal District. Health Sciences Professor. Brasília, Federal District, Brazil. E-mail: karinereisdf@hotmail.com

2 Ph.D. in Fundamental Nursing. Professor of the Health Sciences Faculty Nursing Department and the Post-graduate Program in Nursing of the UnB. Brasília, Federal District, Brazil. E-mail: cristine@unb.br
\end{abstract}

\begin{abstract}
Objective: identify relationships of association between the risk of falls in institutionalized elderly people with polypharmacy and polypathy, as well as to outline the epidemiological profile of its casuistry.

Method: a prospective obseracional study with 271 elderly residents in long-stay institutions in the Federal District (Brazil). The date were a actualized by inferencial statistics.

Results: a monitoring of elderly confirmed the association between polypathology and falls (p: 0.0028), however, it did not follow the trend of other studies in identifying polypharmacy as a risk factor for falls (p: 0.141). Among the most prevalent comorbidities, changes in blood pressure levels (77.4\%), followed by Diabetes Mellitus (27.37\%), depression (17.7\%) and dementia (46.8\%) may be highlighted. The most identified drugs were antihypertensives (73.8\%), sleep inducers (61.2\%), diuretics (50.1\%) and antidepressants (34.3\%).

Conclusion: multiple disabilities associated with chronic-degenerative diseases and the chronic use of medications may interfere with the incidence of falls, ratifying factors related to the diagnosis of risk for falls presented in the NANDA-I Taxonomy I. This contribution to the nurses' diagnostic rationale ensures better evaluation of the elderly, ensuring a care plan focused on prevention and detection of risk conditions.
\end{abstract}

DESCRIPTORS: Health of the elderly. Use of medications. Accidental falls. Nursing diagnosis.

\section{RELAÇÃO DA POLIFARMÁCIA E POLIPATOLOGIA COM A QUEDA DE IDOSOS INSTITUCIONALIZADOS}

\section{RESUMO}

Objetivo: identificar relações de associação entre o risco de queda em idosos intitucionalizados com a polifarmácia e a polipatologia, bem como traçar o perfil epidemiológico desta casuística.

Método: estudo prospectivo, observacional realizado com 271 idosos moradores de instituições de longa permanência do Distrito Federal. Os dados foram atualizados por estatística inferencial.

Resultados: o acompanhamento dos idosos confirmou a associação entre a polipatologia e a queda (p: 0,0028), porém não seguiu a tendência de outros estudos em identificar a polifarmácia como fator de risco de queda (p: 0,141). Entre as comorbidades mais prevalentes destacou-se alteração dos níveis tensionais (77,4\%), seguida de Diabetes Mellitus $(27,37 \%)$, depressão $(17,7 \%)$ e demência $(46,8 \%)$. Já os medicamentos mais identificados foram os anti-hipertensivos $(73,8 \%)$, indutores do sono $(61,2 \%)$, diuréticos $(50,1 \%)$ e antidepressivos $(34,3 \%)$.

Conclusão: que múltiplas incapacidades associado a doenças crônico-degenerativas e o uso crônico de medicamentos, podem interferir na incidência de queda, ratificando os fatores relacionados ao diagnóstico risco de queda presente na Taxonomia I da NANDA-I. Essa contribuição ao raciocínio diagnóstico do enfermeiro garante melhor avaliação do idoso, garantindo um plano de cuidados voltado a prevenção e deteç̧ão de condições de risco.

DESCRITORES: Saúde do idoso. Uso de medicamentos. Acidentes por quedas. Diagnóstico de enfermagem. 


\section{RELACIÓN DE LA POLIFARMACIA Y POLIPATOLOGÍA CON LA CAÍDA DE ADULTOS MAYORES INSTITUCIONALIZADOS}

\section{RESUMEN}

Objetivo: identificar relaciones de asociación entre riesgo de caída en adultos mayores institucionalizados con la polifarmacia y la polipatología, asi como trazar un perfil epidemiológico de esta casuística.

Método: estudio prospectivo, observacional realizado con 271 ancianos residentes de instituciones a largo plazo del Distrito Federal. Los datos han sido actualizados por inferencial.

Resultados: el acompañamiento de adultos mayores confirmó la asociación entre la polipatología y la caída (p: 0,0028), sin embargo no siguió la tendencia de otros estudios en identificar la polifarmacia como factor de riesgo de caída (p: 0,141). Entre las comorbidades más prevalentes se destacaron la alteración de los niveles tensionales (77,4\%), seguida de la Diabetes Mellitus (23, 37\%), depresión (17,7\%) y demencia $(46,8 \%)$. Los medicamentos más identificados fueron los anti-hipertensivos $(73,8 \%)$, inductores del sueño $(61,2 \%)$, diuréticos $(50,1 \%)$ y antidepresivos $(34,3 \%)$.

Conclusión: que multiples incapacidades asociado a enfermedades crónico degenerativas y el uso crónico de medicamentos pueden interferir en la incidencia de caída, ratificando los factores relacionados al diagnóstico de Riesgo de Caída presente en la Taxonomia I de la NANDA-I. Esta contribución al raciocinio diagnostico del enfermero garantiza mejor evaluación del adulto mayor, garantizando un plano de cuidados vinculado a la prevención y detección de condiciones de riesgo.

DESCRIPTORES: Salud del adulto mayor. Uso de medicamentos. Accidentes por caídas. Diagnóstico de enfermería.

\section{INTRODUCTION}

Brazil, as well as other developing countries, has been experiencing a significant growth of its elderly population. In addition to this demographic transition, an epidemiological transition is also observed alongside the changes in the country's health profile, where chronic degenerative diseases have replaced the acute infectious-contagious diseases characteristic of the 1960s. As a consequence of this transition, the use of drugs by this population increases every day, and as a result of the higher prevalence of chronic diseases, the elderly are possibly the most medicalized age group in society since their treatment involves the association of numerous drugs. ${ }^{1-2}$

In association with the physiology of the elderly whose functional reserve is diminished, the processes of absorption, distribution, metabolization and elimination of drugs are differentiated, leading to adverse reactions related to their use. In this context, falls are considered a syndrome due to innumerable risk factors, and they can also be induced by various mechanisms and direct or indirect acts of the medication used.

Falls have a great impact on aging due to high morbidity and high personal, social and economic costs resulting from the damage caused. Falls emphasize the senescence process leading to an important loss of autonomy and quality of life among the elderly, and it can also have repercussions among the caregivers who are encouraged to provide special care to the family member, adapting their whole routine according to recovery or adaptation after falls. ${ }^{3}$
Approximately $28 \%$ to $35 \%$ of people over 65 suffer falls each year, and this proportion rises to $32 \%$ to $42 \%$ in the elderly over 70 years old. However, some literature reviews show that the incidence of falls in a household population aged over 70 can reach up to $49 \%$. In the year 2000 , Brazil ranked third in deaths related to external causes among elderly people living in the State of São Paulo, registering 2,030 deaths related to falls in the age group of 60 or older. Falls ranked first among the causes of death in this group, being responsible for 1,328 cases and representing $31.8 \%$ of the total. ${ }^{4}$

Despite a clear relationship between falls and polypharmacy, studies have shown that the association is more significant with some drugs such as serotonin inhibitors, tricyclic antidepressants, neuroleptics, benzodiazepines, anticonvulsants, and class A antiarrhythmic medications. Each of these drugs has a previously studied configuration regarding their expected adverse reactions, thereby requiring to be identified for rational use. Iatrogenic occurrences due to medications may lead to loss of postural balance associated with the foreign environment in which the elderly are exposed to, leading to falls in this population. ${ }^{5}$

In this article, the possible associations of medication use and the risk of falls in institutionalized elderly in the Federal District (Brazil) is presented, as our objective was to identify causal relationships between polypharmacy and polypathology in the occurrence of falls, in addition to outlining the epidemiological profile of its casuistry. This evaluation will substantiate data collection and nursing diagnosis, supporting nurses in relation to their technical and scientific knowledge to design care plans. 


\section{METHOD}

This is a prospective study implementing an observational design, based on a clipping of the author's master's thesis dissertation. The sample consisted of 271 elderly individuals institutionalized for over six months in institutions of the Federal District, distributed into case and control groups. The case group consisted of 69 elderly individuals who presented the studied outcome of falls, from September/2013 to February/2014, and a control group consisting of 202 elderly people without records of falls in the same period.

The sample consisted of elderly residing in five institutions of the Federal District of different administrative regions and with different types of management (private, philanthropic or philanthropic-private) seeking equity in the sample.

Falls were considered as an unintentional event that resulted in the individual's shifting their position to a level lower than their initial position. ${ }^{6}$

The terms polypharmacy and polypathology were classified according to literature, corresponding to the use of more than five daily medications and more than five comorbidities diagnosed in the patient's medical record, respectively. ${ }^{7}$

The primary database of the study was composed of information collected through a structured script. A data collection instrument was developed to evaluate the association between comorbidities and the use of medications with the occurrence of falls. Professionals who work and have experience in caring for the elderly participated in this evaluation stage. The instrument was initially applied to the first ten seniors from the selected sample list, after which the instrument for data collection was adjusted (pilot test).

Two sets of exploratory variables were considered: sociodemographic (gender, age, marital status, schooling) and health condition indicators (history of falls, comorbidities, functionality, mobility, use of medicines, self-perception about health).

Based on data collection, elderly with or without the record of falls were assessed for the presence of polypharmacy and polypathology. This assessment aimed to identify causal relationships between the variables.

A worksheet in Microsoft Access Program was used for data analysis and the statistical package Statistical Analysis (SAS) performed the inferential statistics. The information collected on the elderly was grouped according to the comparison groups. The association was made through the statistical
Odds Ratio (odds ratio), confidence interval and statistical p-value, based on the chi-square distribution and logistic regression.

The Ethics Committee of the Faculty of Health Sciences of the University of Brasilia (Brazil) approved the study under Process 285577 number 13. All subjects or legal guardians signed the Clear and Informed Consent Form.

\section{RESULTS}

A total of 271 elderly were considered eligible; of these, 202 had no records of falls and 69 had records of falls in the institutions. A total of 111 adverse events were identified. The incidence of falls during the study was $41 \%$.

Regarding the sociodemographic information, it was evidenced that the studied population had a mean age of 78 years, were predominantly female $(57.5 \%)$ and there was a higher prevalence of singles or widowers - $40 \%$ were single and $43.7 \%$ were widowers. Moreover, $48.5 \%$ of the elderly were illiterate and only $27.82 \%$ completed the primary level of schooling. Low schooling had a close relationship with the participation of asylum activities, where $73.43 \%$ of those interviewed did not participate in reading activities. However, art activities and physical activities were significant with adhesion of $69 \%$ and $46 \%$, respectively.

Regarding indicators related to health condition referring to the overall evaluation of the elderly, most have a strong dependence for performing daily activities $(53.1 \%)$, low scores in balance and gait evaluation $(81.1 \%)$ and mental status evaluated as compromised $(87.2 \%)$.

Self-perception about health is a variable considered to be an important criterion of the elderly's health condition and able to predict the survival of this population. We found that $46 \%$ of them considered to be in good health, while $17.7 \%$ reported to be in poor health. Due to cognitive decline, $29.5 \%$ of the elderly were not able to respond.

Regarding comorbidities, the most frequent chronic-degenerative diseases identified from the medical records were hypertension (77.4\%), followed by diabetes $(27.37 \%)$. Depression and dementia also presented high prevalence in the study with frequencies equivalent to $17.7 \%$ and $46.8 \%$, respectively.

By categorizing morbidities according to the number of pathologies diagnosed in the individuals, we noticed that only $15.8 \%$ of the elderly had more than five pathologies. As for the use of medications, the elderly maintained the national trend of poly- 
pharmacy, where $69.7 \%$ of the elderly in the sample used five or more medications. Antihypertensives (73.8\%), sleep inducers $(61.2 \%)$, diuretics $(50.1 \%)$ and antidepressants $(34.3 \%)$ were the most common.

Of the 69 elderly fall victims, we found that $100 \%$ of them used medication on a chronic basis.
Using inferential statistics shown in table 1, we found odds ratios (OR) of 1.61, with a confidence interval (CI) of 0.86 to 3.02 for the use of more than five medications, characterizing a more severe polypharmacy. However, this variable had no statistically significant relationship ( $p=0.141)$ with falls.

Table 1 - Association between polypathology and polypharmacy and the record of falls Brasília, DF, Brasil, September/2013 to February/2014. $(n=271)$

\begin{tabular}{lccccc}
\hline Risk factors & $\begin{array}{c}\text { Falls } \\
\text { n: } \mathbf{6 9}(\mathbf{\%})\end{array}$ & $\begin{array}{c}\text { No falls } \\
\text { n: 202 (\%) }\end{array}$ & OR & 95\% CI & p-value \\
\hline Higher polypathology & $19(25.54 \%)$ & $24(11.88 \%)$ & 2.82 & $1.43-5.56$ & 0.0028 \\
Lower polypathology & $50(72.4 \%)$ & $178(88.11 \%)$ & & $0.86-3.02$ & 0.141 \\
\hline Higher polypharmacy & $53(76.81 \%)$ & $136(67.33 \%)$ & 1.61 & & \\
Lower polypharmacy & $16(23.18 \%)$ & $66(32.67 \%)$ & & & \\
\hline
\end{tabular}

Table 2 and figure 1 show that polypathology had an increasing relationship with the risk of falls (statistically significant with $\mathrm{p}=0.04$, as shown in Table 2), however the same did not occur in relation to polypharmacy $(p=0.86$, as shown in Table 3). This shows that although both variables are closely related, they did not present the same association with falls, thus indicating significant differences, possibly due to confounding variables.

Table 2 - Association between falls and the number of pathologies. Brasília, DF, Brazil, September/2013 to February/2014

\begin{tabular}{lll}
\hline Polypathology & & \\
\hline Number of morbidities & Fall rate & P-value trend \\
\hline 0 & 0.33 & \\
1 & 0.17 & \\
2 & 0.17 & \\
3 & 0.23 & 0.0465 \\
4 & 0.27 & \\
5 & 0.46 & \\
6 & 0.40 & \\
7 & 0.57 & \\
\hline
\end{tabular}

Figure 1 shows the association of fall rates through OR and CI, and the number of comorbidities detected in the elderly's medical records. It is possible to observe an increasing and significant $(p=0.0465)$ causal relationship between falls and polypathology. Nonetheless, it is important to mention that an association of pathologies that could lead to an increased risk of falls was not carried out. 


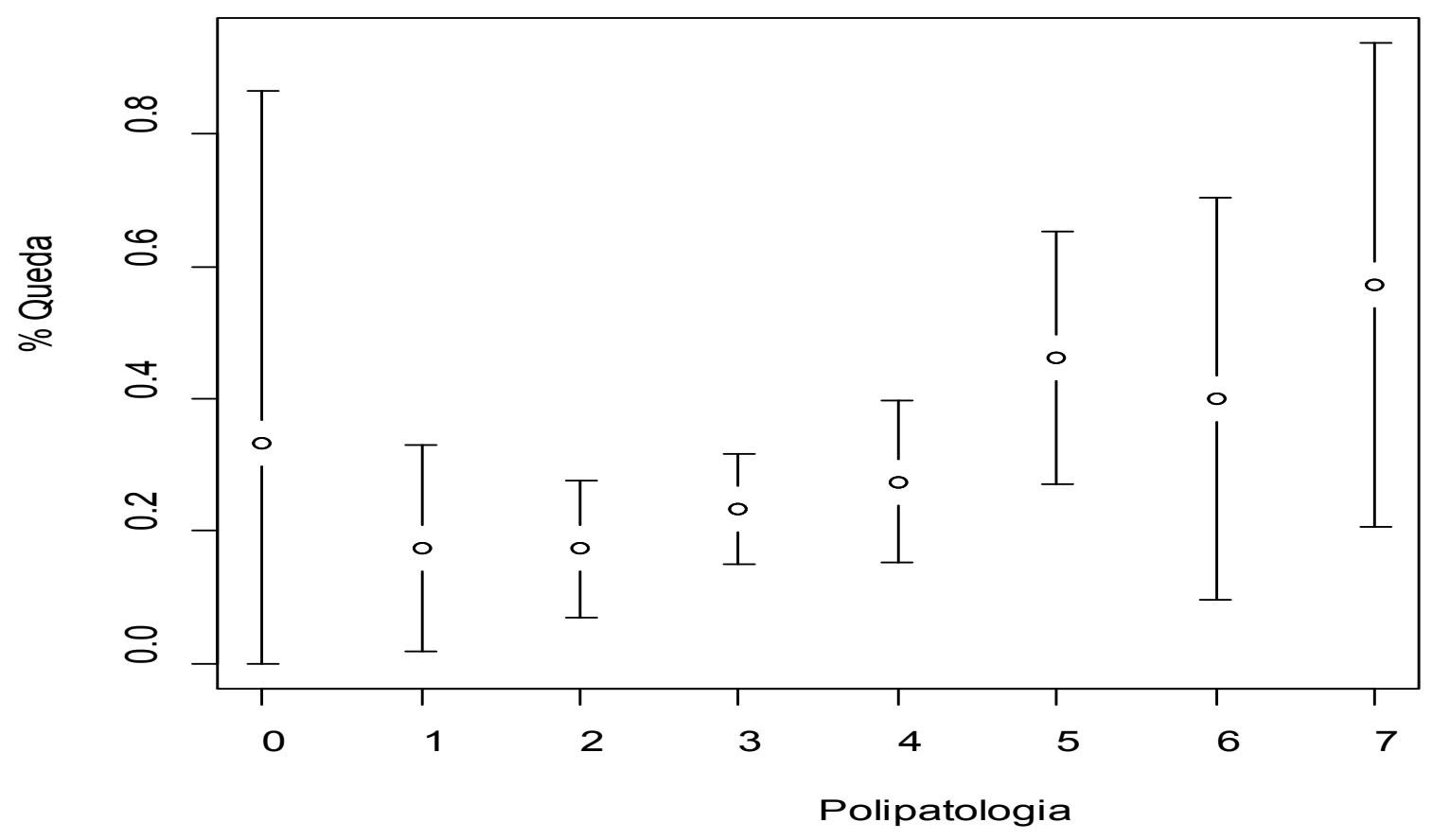

Figure 1 - Association between falls and the number of comorbidities diagnosed in the elderly. Brasília, DF, Brazil, September/2013 to February/2014

In table 3, the causal relationship between polypharmacy and the increasing rate of falls was not identified. Individuals with drug abuse (nine or more medications) unusually had a lower rate of falls than elderly using three to nine medications, where $\mathrm{p}$-value was not significant $(\mathrm{p}=0.8669)$.

Table 3 - Use of medications and risk of falling rate. Brasília, DF, Brazil, September/2013 to February/2014

\section{Polypharmacy}

\section{Number of medications}

Up to 2 medications

From 3 to 5 medications

From 6 to 8 medications

From 9 to 11 medications

More than 12 medications p-value trend

0.27

0.32

0.8696

0.15

0.13
Figure 2 corroborates the data from table 3 , in which there is an increasing relationship up to the use of six medications; however, when the elderly use more than nine medications this causal relationship with falls disappears, decreasing the rate of falls associated with using medication. 


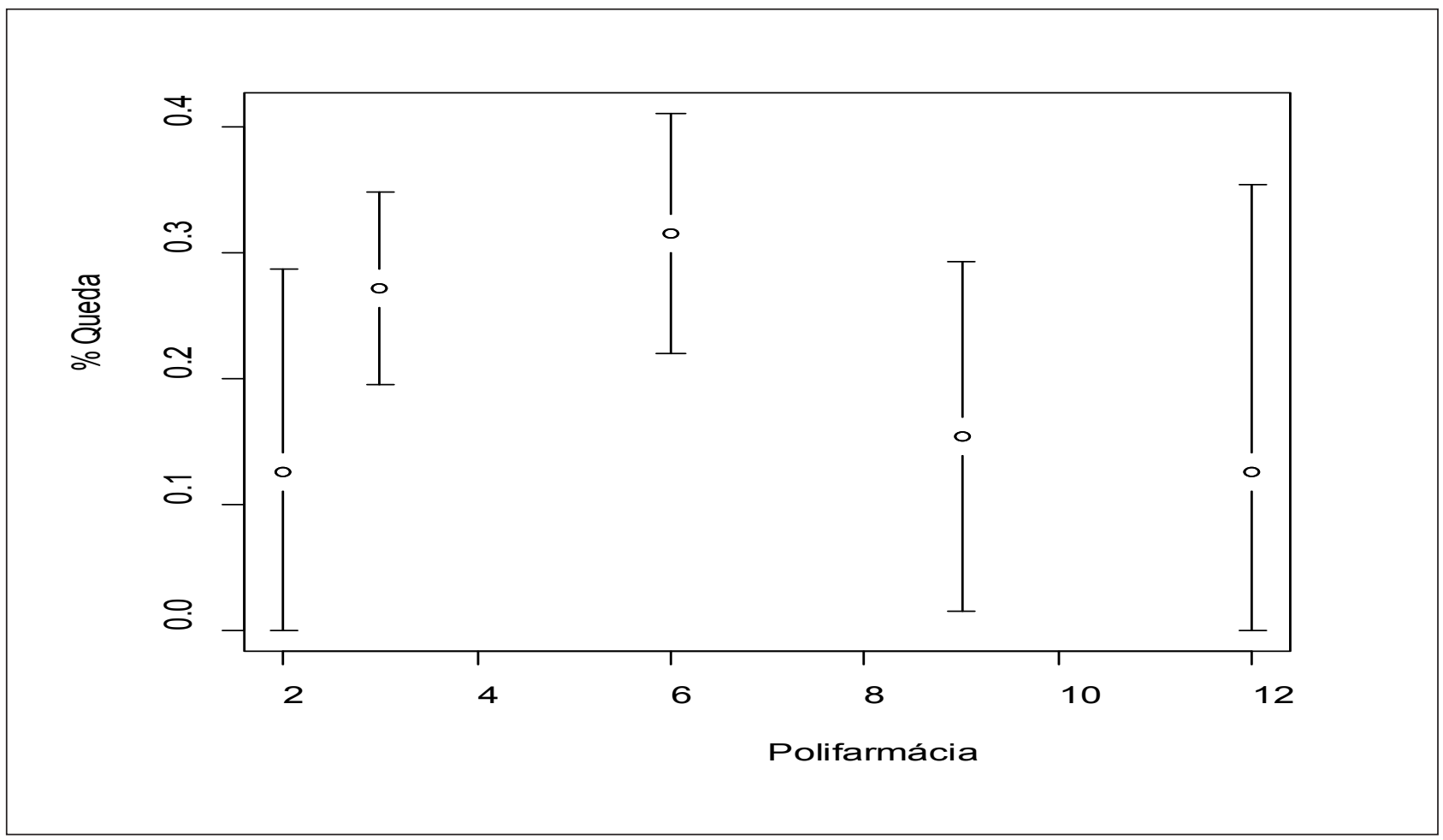

Figure 2 - Risk of falls rate and the number of medications used by the elderly. Brasília, DF, Brazil, September/2013 to February/2014

\section{DISCUSSION}

Associations between multiple disabilities, polypathology and polypharmacy are common in institutionalized elderly persons. ${ }^{2-3}$ Among the investigated morbidities in evaluating the institutionalized elderly population, diseases of the spine/ back $(40 \%)$, hypertension $(37.2 \%)$ and arthritis or rheumatism $(32.1 \%)$ were the most common. ${ }^{1}$ In another investigation about the sociodemographic profile of the elderly assigned to a Basic Health Unit with a history of falls, chronic diseases with higher prevalence were related to systemic arterial hypertension, as cited by $63.3 \%$ of the elderly, as well as visual deficit $(70 \%)$ and osteoarticular disease $(62.7 \%) .{ }^{8} \mathrm{New}$ evidence suggests a high incidence of the elderly population in a number of comorbidities, with $98.3 \%$ presenting from 4 to 7 morbidities, including vision problems $(78.1 \%)$, back problems $(63.3 \%)$, arterial hypertension $(60.9 \%)$ and varicose veins $(53.1 \%)$ being prominent. ${ }^{9}$

The present study confirms the high prevalence of chronic degenerative diseases affecting the elderly, where hypertension (77.4\%) followed by dementia (46.86\%), diabetes Mellitus (27.3\%) and cerebrovascular accident (CVA) (26.94\%) stand out.
Several studies also include osteomuscular, genitourinary, psychiatric and sensorial diseases as factors that more often predispose elderly to the adverse event of falls. ${ }^{10}$ This fact confirms the importance of evaluating comorbidities while reporting adverse events. The reality is that several pathologies increase the vulnerability of this population to falls even more, making the situation of the elderly even more unstable. The best interdisciplinary evaluation is therefore essential, especially when faced with a prevalence where only $14 \%$ of the elderly interviewed are free of chronic diseases. ${ }^{11}$

The study identified polypharmacy in $69.7 \%$ of the elderly sample using five or more medications. The fact is that most of the elderly make use of at least one drug, and about a third of them use multiple drugs. This indiscriminate and irrational use can lead to excessive consumption of unnecessary or non-recommended products, as well as underutilization of other essential methods for disease control. ${ }^{12}$ Excessive use of medications in a population where only $15.8 \%$ had more than five pathologies, as indicated in the present study, demonstrates similar values to international research, where polypharmacy associated with the diversity of medication used by the elderly contrasts with the 
low prevalence of pathologies, which can characterize iatrogenesis from excessive drug consumption and the high medicalization of this age group. ${ }^{12}$

Prescribing medications for the purpose of correcting side effects from other previously administered agents is very common. This condition, however, can lead to a chain of undesirable reactions known as cascade iatrogenesis. ${ }^{8,12}$ This characteristic of clinical practice may be related to the high prevalence of polypharmacy, which is not consistent with the presence of few pathologies. It is also possible to infer about the possible effect of the higher chronic disease incidence in the studied sample which require numerous drug treatments, thus leading to polypharmacy.

In this study, the evaluated elderly did not present more than five pathologies, despite following the national trend related to an excessive use of medications (polypharmacy). However, inferential statistics have shown that multiple comorbidities are increasingly related to the occurrence of falls, a fact that does not occur with polypharmacy. The increasing associative relationship with falls when using two to six medications disappears when elderly make use of more than six medications. This rejection of the alternative hypothesis possibly occurs due to the severity of functional dependence and cognitive decline presented by the elderly, where their using of more than five medications was not a predictor for the increased risk of falls. This data is verified through studies with elderly people living in long-term institutions in Germany, where a positive association between falls and partially dependent elderly was found; nevertheless, this relationship was not found between independent and the totally dependent elderly people. It is noteworthy that the group of partially dependent elderly demands more attention since their functional decline is not determinant for immobility, increasing the chance and risk of falls compared to those who are totally dependent. ${ }^{13}$

In order to reinforce evidence about the impact of polypathology on falls, a cross-sectional study of 4,050 British women aged 60 to 79 years showed that chronic diseases and multiple pathologies are more important predicting factors for falls than polypharmacy. ${ }^{14}$ The researchers ratified the increase in the prevalence of the adverse event of "falls" in individuals affected by various chronic diseases, but the relation of falls with the number of drugs used by the elderly was not evidenced. In the same study, only hypnotics, anxiolytics and antidepressants showed significant associations for the increase in the number of falls. ${ }^{14}$
Contrary to the findings of the present study, other research has shown that the risk of falls significantly increases with the number of medications used daily by the elderly $(\mathrm{p}<0.0001) .{ }^{15}$ After adjusting for the number of comorbidities and disabilities, polypharmacy remains a significant risk factor. This causal relationship is also demonstrated in other studies, showing that individuals using five or more medications had a higher percentage frequency of falls than those who used fewer drugs. Apparently, the pharmaceutical classes more associated to the event were psychoactive and diuretic drugs. ${ }^{5,15}$

The growth in the number of elderly people who use some type of drug for chronic diseases and/ or to improve their quality of life increases every day. Several studies evaluating the use of drugs have shown that in addition to using a large number of pharmaceutical specialties among the elderly, there is a higher prevalence of the use of certain groups of drugs, such as analgesics, anti-inflammatories and psychotropic drugs. ${ }^{8}$ It was found that risk variables for falls and fracture in the elderly population are associated with medication use, since they cause drowsiness, alter balance, muscle tone and/or hypotension. ${ }^{16}$ Relevant findings in the literature on falls in the elderly have also showed statistically significant relationships $(p=0.035)$ between falls and medication use by the elderly. ${ }^{17}$

Polypharmacy associated with inadequate prescription of medications is also related to the worse prognosis resulting from falls. ${ }^{18-19}$ Some authors have investigated the association between the use of medication and the occurrence of fracture due to falls by means of inferential statistics. ${ }^{20}$ In this study, the increase in the risk of fractures was 96\% (OR:1.96, 1.16-3.30) of the cases among users of calcium channel blockers, and $109 \%$ in the elderly using bezodazepines (OR:2.09, 1.08-4.05).

Numerous medications are associated with increased risk of falls and fractures. In analyzing fractures resulting from falls in hospitalized patients, it was observed that muscle relaxants were associated with an increased risk of fractures resulting from falls. Causal inferences such as weakness, drowsiness, sedation and anticholinergic effects predisposing to falls can be made. ${ }^{20}$ Further regarding drug use, researchers have identified polypharmacyrelated factors in institutionalized elderly. Factors such as cognitive deficit, use of cardiovascular and psychotropic medication, in addition to more than five comorbidities and institutionalization duration have demonstrated a significant relationship with the presence of polypharmacy. ${ }^{21}$ 
The fact is that the worsening condition of the elderly population residing in long-term institutions is also linked to drug administration and the absence of continuous evaluation of these individuals. The elderly have peculiarities regarding medication use in relation to their functional reserves and physiological changes due to the aging process. Such peculiarities therefore greatly interfere in the pharmacokinetics and the medicinal properties of the drugs, which may lead to pharmacological effects such as an increase in adverse reactions. ${ }^{17,22}$ All of these changes that the elderly undergo in their clinical conditions and the concomitant use of medications stand out as factors that should be evaluated by the health team. ${ }^{23}$ In this context, this study ratifies the NANDA-I Taxonomy through the diagnosis of the risk of falls. Nurses evaluating the risk factors guarantees prevention of the adverse event of falls, and their evaluation should be used to develop care plans.

However, the present study has some limitations that could interfere with the obtained results such as possible memory bias due to implementing the recall method over the history of falls in the last six months. Other limiting factors are the absence of protocols for evaluating and notifying fall events in long-term institutions, leading to losses or underreported incidence of the event in the institutions.

\section{CONCLUSION}

The main objective of the present study was to identify causal relationships involving falls in institutionalized elderly in relation to medication use and the presence of several comorbidities. Based on the research we can conclude that the use of five or more drugs was not significant for falls, despite a high prevalence in the elderly studied, while being affected by numerous diseases implied in higher risk for the occurrence of falls in the elderly.

The process of determining causality of falls involves multiple factors. The presence of numerous comorbidities such as neurological diseases, dementia syndromes, cardiovascular and osteoarticular diseases lead to a reduction in physical capacity, and is linked to the inability of the static equilibrium, as confirmed in the present study associated with medication use.

Polypharmacy is another factor related to the event of falls. The proportion of elderly using inappropriate drugs is an important indicator of the quality of care. The use of multiple products, inappropriate drug prescription for the elderly, the use of two or more drugs with the same pharmacological activity and inadequate training of the health team favor the appearance of adverse effects and interactions, thereby causing cumulative toxicity, as well as reducing adherence to treatment and causing medication errors. Apart from these inadequacies, there are also assistance costs and repercussions resulting from medication use, such as developing and increasing the risk factor for falls.

Preventing falls and their resulting consequences is a major challenge, as developing measures necessary to control falls depends on the involvement of several agents. Due to its multifactorial nature, preventive intervention should also be multidimensional involving well-trained professionals, including nurses who understand that the country is going through an aging process and that they need to be prepared to deal with new and old demands of this growing population. Therefore, health professionals should be trained and sensitized to the issue, equipped for evaluating and conducting interventions, and give special attention to elderly health promotion and education.

\section{REFERENCES}

1. Alvares LM, Lima RC, Silva RA. Ocorrência de quedas em idosos residentes em instituições de longa permanência em Pelotas, Rio Grande do Sul, Brasil. Cad. Saúde Pública. 2010; 26(1):31-40.

2. Gomes ECC, Marques APO, Leal MCC, Barros BP. Fatores associados ao risco de quedas em idosos institucionalizados: uma revisão integrativa. Ciênc. saúde coletiva. 2014; 19(8):3543-51.

3. Bentes ACO, Pedroso JS, Maciel CAB. O idoso nas instituições de longa permanência: uma revisão bibliográfica. Aletheia. 2012; 38(39):196-205.

4. Gawryszewski VP. A importância das quedas no mesmo nível entre idosos no estado de São Paulo. Rev. Assoc. Med Bras. 2010; 56(2):162-7.

5. Rezende CP, Gaede C, Gonçalves MR, Oliveira EC. Queda entre idosos no Brasil e sua relação com o uso de medicamentos: revisão sistemática. Cad. Saúde Pública. 2012; 28(12): 2223-35.

6. Organização Mundial da Saúde. Classificação Estatística Internacional de Doenças e Problemas Relacionados à Saúde - CID-10. [2014 Jul 13]. Disponível em: http://www.datasus.gov.br/cid10/ v2008/cid10.htm

7. John CW, Kathriyn JR, Richardson MS, Carlo AM, Mathew OW, Pharm PD. Meta-analysis of the Impact of 9 medication classes on falls in elderly persons. Arch Intern Med. 2009; 169(21):1952-60.

8. Santos RKM, Maciel ACC, Britto, HMJS, Lima JCC, Souza TO. Prevalence and factors associated with the 
risk of falls among the elderly registred in a primary healthcare unit of the city of Natal in the state of Rio Grande do Norte, Brasil. Ciência saúde coletiva. 2015; 20(12):3753-62.

9. Tavares DMS and Dias FA. Functional capactiy, morbidities and quality of life of the elderly. Texto contexto - enferm. 2012; 21(1):112-20.

10. Abreu HCA, Reiners AAO, Azevedo RCS, Silva AMC, Abreu DROM, Oliveira AD. Incidência e fatores preditores de quedas de idosos hospitalizados. Rev. Saúde Pública. 2015; 49:37.

11. Valentin FCV, Fonseca MCR, Santos MO, Santos BMO. Avaliação do equilíbrio postural e dos fatores ambientais relacionados às quedas em idosos de instituições de longa permanência. Estudos Interdisciplinares sobre o Envelhecimento. 2013; 14(2):207-24.

12. Gonzalez RP, Castillo PV, Hernández SG, Quintana GE, Gutiérrez GM. Polifarmacia en el adulto mayor: ¿es posible su prevención? Rev Ciencias Médicas. 2014; 18(5):791-801.

13. Kron M, Loy S, Sturm E. Risk indicators for falls in institutionalized frail elderly. Am J Epidemiol. 2003; 158(1):645-53.

14. Lawlor DA, Patel R. Association between falls in elderly women and chronic desease and drug use: cross sectional study. BMJ. 2003; 327(7417):712-7.

15. Zeire JP, Dieleman A, Hofman HAP, Pols TJM, Van Der Cammen BH. Polypharmacy and falls in the middle age and elderly population. British Journal of Clinical Pharmacology. 2005; 61(2):218-23.
16. Hamra A, Ribeiro MB, Domingues OF. Correlação entre fratura por queda em idosos e uso prévio de medicamentos. Acta Ortop. Bras. 2007; 15(3):143-5.

17. Lojudice DC, Laprega MR, Rodrigues RAP. Queda de idosos institucionalizados: ocorrência e fatores associados. Rev Bras Geriatria Gerontologia. 2010; 13(3):403-12.

18. Del Duca GF, Ante DL, Hallal PC. Quedas e fraturas entre residentes de instituições de longa permanência para idosos. Rev. Brasileira de Epidemiologia. 2013; 16(1):68-76.

19. Manso MEG, Biffi ECA, Gerardi TJ. Prescrição inadequada de medicamentos a idosos portadores de doenças crônicas em um plano de saúde no município de São Paulo, Brasil. Rev Bras Geriatr Gerontol. 2015; 18(1):151-64

20. Coutinho ESF, Flecher A, Block KV, Rodrigues LC. Risk factors for falls with severe fracture in elderly people living in a middle-income country: a case control study. BMC Geriatrics. 2008; 8(1):1-7.

21. Lucchetti G, Granero AL, Pires SL, G1orzoni ML. Fatores associados a polifarmácia em idosos institucionalizados. Rev Bras Geriatria Gerontologia. 2010; 13(1):51-8.

22. Secoli SR. Polifarmácia: interações e reações adversas no uso de medicamentos por idosos. Rev Bras Enferm. 2010; 63(1):136-40.

23. Martins GA, Acurcio FA, Franceschini SCC, Priore SE, Ribeiro EQ. Uso de medicamentos potencialmente inadequados entre idosos do município de Viçosa, Minas Gerais, Brasil: um inquérito de base populacional. Cad Saúde Pública. 2015;31(11):2401-12. 